This is the accepted author version of the article. The completed one is published here, please use this reference if citing the article:

Jan Christoffer, Andersen \& Sandberg, Sveinung (2018). Islamic State Propaganda: Between social movement framing and subcultural provocation. Terrorism and Political Violence. doi: $\underline{10.1080 / 09546553.2018 .1484356}$ 


\title{
Islamic State Propaganda Between social movement framing and subcultural provocation
}

\begin{abstract}
The Islamic State (IS) has become notorious for violent, brutal actions and the presentation of these actions in social and mainstream media. Excessive violence creates a spectacle for the news media. However, IS propaganda also emphasizes its role in state building and its engagement in social and welfare work. This twofold propaganda enables the mobilization of different audiences, but it also sends conflicting messages about the organization. In this article, we study the e-magazine Dabiq, emphasizing their methods of gaining support and attempting to recruit Western participants to violent jihadism. We use theories of social movement and subculture to reveal some of the underlying tensions in IS's communicative strategies. The analysis first identifies how IS frame their propaganda attempting to mobilize widespread support. Then, it highlights another dimension of IS's rhetoric; provocations, the creation of sensationalist spectacles of violence and links to excitement seeking, stardom and popular culture. We conclude that combining general anti-Western rhetoric and religious imagery with extraordinary depictions of violence has been both a strength and flaw in the organization's propaganda.
\end{abstract}




\section{Introduction}

On June 29, 2014, The Islamic State (IS) - also known as ISIS or Daesh - officially declared the establishment of an Islamic Caliphate in Syria and Iraq. Abu Bakr al-Baghdadi claimed the title of Caliph and leader of the world's Muslim population. ${ }^{1}$ The organization has had a pervasive presence in both social media and the mainstream media, overshadowing other terrorist organizations such as Al Qaeda (AQ), al Shabaab, Hamas and Hizballah. In its attempts to appeal to the sensationalist news media and gain attention, provoke and incite fear, IS has constructed several spectacles, including the destruction of artwork, brutal murders and executions. Although these actions are only a small part of the propaganda IS promotes, they have become the focus of the mainstream media. ${ }^{2}$ However, IS has also been running a more positive propaganda campaign, emphasizing the state-building and social welfare schemes run by the organization. ${ }^{3}$

The goal of IS was to create an Islamic state, which they described as a caliphate. In their state-building effort, the organization depended on some mainstream support to gain financial aid and mobilize families to migrate to the parts of Syria and Iraq that IS had occupied. When trying to build a state, the promotion of explicit violence can be considered excessive and unnecessary, deterring individuals who would otherwise support the organization. ${ }^{4}$ Disagreements over the degree of violence was one of the reasons for the break between IS and other violent jihadist organizations. IS was considered too brutal, and Al Qaeda and the Nusra Front wanted a more civilized approach to win the hearts and minds of the Syrian people. ${ }^{5}$ As Byman points out, the brutality of IS was not only a by-product of war, but a deliberate strategy. ${ }^{6}$

Examining the organization's characteristics as both a social movement and a subculture can be helpful when attempting to understand the complex message of IS propaganda. Social movement theory has contributed important insights into violent jihadist organizations. ${ }^{7}$ By focusing on the broader dynamics and processes of political mobilization it is possible to reveal how these organizations frame their message to reach a large audience. At the same time there is only a small minority that is drawn towards terrorist organizations. In recent years in Europe there has been a trend that radicalized individuals and potential terrorists have a background in violent and criminal subcultures. ${ }^{8}$ In line with this, previous research has established that subcultural theory too is crucial to understanding radicalization and terrorism. ${ }^{9}$ Despite the many studies of terrorist organisations using both social movement and subcultural theory, thus far, no one has combined the two, or discussed the possible tensions between them in terms of organizational rhetoric. 
We use a qualitative text analysis of Dabiq to address these issues, demonstrating the ways in which IS propaganda mobilizes broad support using both widespread jihadist rhetoric and social movement frames. Following subcultural logic, IS uses violence as a spectacle to appeal to excitement-seeking youth. The result of these two communicative approaches is the ambiguity of IS rhetoric when targeting a Western audience.

\section{IS and Dabiq}

IS was formerly known as Al Qaeda in Iraq (AQI) and was founded by Abu Musab alZarqawi, who died in an American air assault in 2006. The organization was previously governed by Al Qaeda, but internal conflicts ended the collaboration. ${ }^{10}$ After conquering large parts of the Iraqi Sunni heartland in June 2014, the organization attracted the attention of the global media under the new name the Islamic State of Iraq and Syria (ISIS). They surprised international society with their swift advances, seizing roughly a third of Iraqi and Syrian territories in three months with an inferior military force. ${ }^{11}$ McCants offers three main reasons for the establishment and initial success of IS. First, the US withdrawal from Iraq and the insurgency in Syria played out in favour of IS and resulted in a powerful base in Syria. Second, Abu Bakr al-Baghdadi's credibility as a leader was greater than that of his predecessors. Finally, IS proclaimed the reestablishment of the caliphate, which solidified their legitimacy. ${ }^{12}$ Their success was short-lived, and three years later in 2017 the group lost control of their territory and the caliphate had fallen, reverting the group back into a terrorist network. $^{13}$

IS's media strategy included an extensive online presence and direct control of media output. ${ }^{14}$ This propaganda includes pictures, magazines, videos, music and even videogames ${ }^{15}$ that are shared on social media and different Internet sites. ${ }^{16}$ The e-magazine Dabiq has emerged as an important vehicle for IS propaganda toward a Western audience. Before the attack on Mosul in June 2014, IS media statements were issued through two different magazines. Military reports where promoted through Islamic State news (ISN) and political reporting was conducted through Islamic State Report (ISR). These magazines were combined into Dabiq after the declaration of the caliphate. ${ }^{17}$ The magazine is well designed and can be seen as sophisticated and modern, resembling Western news or entertainment magazines in form. It is written or translated into English and French to reach potential Western recruits, including a large group of marginalized excitement-seeking young men, but since it is an e-magazine it is difficult to know how many people who actually reads it. ${ }^{18}$ The 
magazine also targets Western policymakers and works as a corrective document for members of IS. ${ }^{19}$

Dabiq is published by the media channel al-Hayat Media Center. The name of the magazine is taken from the small town of Dabiq in northern Aleppo, Syria. The town does not hold any significance in size or offer any specific advantage as a military position, but according to apocalyptic prophecies in Islam, it is the place of the last battle between Muslims and their enemies. ${ }^{20}$ The magazine represents IS as an organization and often refrains from crediting individual authors. ${ }^{21}$ It gives readers an impression of religious legitimacy and authenticity by frequently citing verses from the Koran, hadiths, and suras, as well as citing significant Islamist figures and high ranking individuals of IS. The magazine includes longer articles and reportages while also offering shorter reports, statements and eye-catching advertisements. ${ }^{22}$ The magazine can generally be divided into two types of content. The first type covers reportages about state building, aid work, military successes, religious practice and history. The second type involves images and texts about the destruction of historical artefacts, child soldiers, brutal murders and executions.

Previous research on Dabiq has analysed its strategic and doctrinal message, ${ }^{23}$ often using a quantitative,${ }^{24}$ multimodal,${ }^{25}$ or visual approach.${ }^{26}$ It has also been compared to $\mathrm{Al}$ Qaeda's e-magazines Inspire and Resurgence. ${ }^{27}$ Few have emphasized the ambiguity in the rhetoric or examined it in light of social movement and subcultural theory. The brutality displayed by IS has generally been explained by the local context of prolonged historical conflicts and brutal actions conducted by all parties. ${ }^{28}$ However, these issues do not fully explain the imagery and promotion of violence aimed at a Western audience.

\section{Social movements and subcultures}

Social movement theory (SMT) is a wide and heterogeneous field within sociology and political science, and it contains a diverse range of analytical frameworks that are used to explore different dynamics within social movements. ${ }^{29}$ No hegemonic definition of a social movement exists, but Zald and McCarthy define it as "a set of opinions and beliefs in a population representing preferences for changing some elements of the social structure or reward distribution, or both, of a society. " ${ }^{30}$ Collective action framing describes the processes of meaning construction ${ }^{31}$ and focuses on "the social production and dissemination of meaning and on how individuals come to conceptualize themselves as a collectivity." 32 Framing theory is one of three central traditions in social movement studies, the other two 
being political opportunities and mobilizing structures. ${ }^{33}$ Collective action framing is particularly relevant when studying social movement rhetoric and propaganda.

The key principle of framing theory is that "events rarely speak for themselves," and different frames compete to be the authoritative interpretation. ${ }^{34}$ Benford and Snow identify three central framing tasks. Initially, movements construct frames that diagnose a condition as a problem that demands change, which includes the attribution of blame and responsibility. Then, the movement will offer solutions to the problem, which includes specific tactics and strategies intended to alleviate injustice. Finally, the movement will offer a reason to motivate and support collective action. ${ }^{35}$ Combined, these constitute the collective action frames or the "action-oriented sets of beliefs and meaning" that mobilize participants and activities in social movement organizations. ${ }^{36}$

While much of the content in Dabiq can be characterized as collective action framing, a substantial part of it does not immediately fit within this type of framework. Arguably, this other content can be better understood using subculture theory. Subcultural studies are often seen as a response to the realization that society includes a multitude of social practices "some of which are 'alternative' or 'unconventional,' others of which are transgressive or even oppositional." ${ }^{37}$ This theory was introduced by the Chicago school of sociology ${ }^{38}$ as a naturalistic perspective emphasizing the "normality of deviance" as opposed to the established pathological approach. ${ }^{39}$ Subcultures are frequently framed as being in some way oppositional to mainstream society, which is most evident in The Birmingham School's neo-Marxist framework. ${ }^{40}$ This school also contributed to expanding the methodological repertoire of subcultural studies by turning their emphasis towards a semiotic method and identifying style as "the key to subcultural 'meaning' and subcultural distinction." 41 There are many definitions of subcultures, but Gelder captures the basic idea in the following definition:

Subcultures are groups of people that are in some way represented as non-normative and/or marginal through their particular interest and practices, through what they are, what they do and where they do it. They may represent themselves in this way, since subcultures are usually well aware of their differences, bemoaning them, relishing them, exploiting them, and so on. But they will also be represented like this by others, who in response can bring an entire apparatus of social classification and regulation to bear upon them. ${ }^{42}$ 
Violent radicalization and participation in terrorist organizations are not only instrumental acts for political purposes but also expressive and emotional actions motivated by excitement and a search for the larger meaning of life. ${ }^{43}$ From this perspective, extreme Islamism can also be a way for marginalized groups and individuals to retaliate against a society from which they feel excluded. ${ }^{44}$ Jihadism also entails a seductive culture of "artistic products and social practices" with no military or strategic purpose. ${ }^{45}$ Subcultural theory can further be used to understand the cultural architecture behind the subcultural style of jihadism as well as the attraction of subcultures in the absence of status frustration and social and financial exclusion. ${ }^{46}$

The concept of subcultures has been problematized due to its downplaying of local variation and fragmentation in youth style. ${ }^{47}$ Other conceptualizations may arguably be better for avoiding homogeneous conceptualizations of cultures. ${ }^{48}$ Three characteristics of what is traditionally described as a subculture are still relevant to understanding IS propaganda. First, as seen in Gelders definition, many subcultures actively attempt to provoke mainstream society. Second, some subcultures celebrate violence and embrace machismo identity, such as counter school cultures, ${ }^{49}$ or violent street cultures ${ }^{50}$ For groups of marginalized youths, these violent cultures may be a symbolic resource and a point of imitation for both opposition and resistance. Finally, subcultures are closely related to popular culture and can be a space in which to seek excitement.

ICCT estimates the total number of foreign fighters from states part of the EU was between 3922-4294 persons. The majority came from France, Germany, United Kingdom and Belgium, and between 6 and 23 percent are converts. UNOCT describes the typical foreign fighter as an economically and educationally disadvantaged young male. ${ }^{51}$ When using the concept of subculture about IS, we are specifically pointing towards Western recruits, and how their subculture is formed in relation to the Western society they feel alienated from. There are great differences between gangs and other criminal subcultures and terrorist organizations, for example in the purpose and nature of violence, excitement seeking, and masculinity, but there are also important similarities. ${ }^{52}$ A recent trend is that many European IS recruits have a background in violent and criminal subcultures, and the reason for this might be similarities between street culture and jihadist subcultures emerging in the West. ${ }^{53}$ When using the concept subculture in this paper, we emphasize these similarities.

IS applies "a vast cultural 'toolkit' of ideas, beliefs, and narratives to target multiple audiences" to gain support for their political aims and objectives. ${ }^{54}$ This study uses insights from both social movement and subculture theory to understand IS's rhetoric in Dabiq. We do 
not argue that IS can be characterized as either a social movement or a subculture but that insights from these research traditions can help us understand the underlying tensions in the organization's propaganda. We analyze the rhetoric in these magazines as attempts at reaching different audiences. This is rhetorical or framing analysis, and not an attempt to establish "root causes" 55 of radicalization. The aim is to describe the main characteristics of IS propaganda, to understand its appeal to different audiences, and to discuss possible effects of the rhetoric.

\section{Methodology}

This study is based on 11 issues of the e-magazine Dabiq, which comprises 670 pages published between July 2014 and August 2015. The magazine uses numerous textual highlights and visual expressions, and a systematic tabularization was conducted to give a comprehensible analysis of its content. A detailed analysis of both textual and visual themes was coded based on the emerging content, which was divided into the main topics covered and promoted (e.g., military, politics, religion, media, health) as well as the prescribed format (e.g., article, report, photo report, poem) of the published themes. Using social movement theory, the content was further coded into the categories of diagnostic, prognostic and motivation framing, which constitutes the first part of the analysis below. Subcultural theory was used to code data into different subcultural traits such as provocation, violence and machismo, and excitement seeking, which makes up the last part of the analysis.

Some themes and extracts from Dabiq texts could potentially be covered by both categories of social movement framing and the subcultural categories we constructed. This highlights the potential problems of categorization in general as well as the closely intertwined relationship between these two forms of rhetoric in IS propaganda. Therefore, we examine these analytically derived categorizations to highlight the different forms of rhetoric in IS propaganda. This is a common approach in qualitative method and analysis. ${ }^{56}$ Notably, we only discuss IS rhetoric in Dabiq aimed at a Western audience and not the organization or IS propaganda in general. Moreover, changes on the battlefield and in the organization are continuous, resulting in information becoming quickly outdated (for example, the magazine changed its name to Rumiyah after the loss of Dabiq). However, we still believe our analysis can shed light on more general and long-lasting characteristics and ambiguities in the organization.

\section{IS propaganda as social movement framing}


The success of IS as a social movement depends on the organization's "ability to promote a specific version of reality and to make this version resonate with the worldview of potential recruits." ${ }^{57}$ IS's diagnostic framing presents concrete problems such as identifying enemies, the unjust treatment of Muslims, Western values and practices that demand immediate change. Collective action framing further provides solutions in prognostic frames such as the construction of the Caliphate, jihad, emigrations and the implementation of sharia. Finally, in an effort to motivate individuals to engage in actions supporting the organization, IS appeals to emotions, highlights their success and emphasizes the severity of their message. ${ }^{58}$ IS also maintains credibility by substantiating promoted claims through frame consistency, primarily by leaning on religious scripture.

\section{The problem: Western government, Western values and false Islam}

In an effort to create a common framework for action, different actors need to operate with a more or less shared understanding of what they define as problematic. ${ }^{59}$ As a social movement, IS construct frames that diagnose a condition as a problem that needs to be corrected, including ascribing responsibility and allocating blame. ${ }^{60}$ Dabiq presents several different topics that IS identifies as major conditions or issues in need of change.

IS accuses Western governments of oppressing the Muslim people in a systematic manner. The former official spokesman for IS, Abu Muhammad al-Adnani al-Shami, condemned the US and Europe in a speech released in September 2014. The organization claims that the US-led coalition was an invading force of infidels responsible for starting the war in Syria and Iraq. ${ }^{61}$

O Americans, and O Europeans, the Islamic State did not initiate a war against you, as your governments and media try to make you believe. It is you who started the transgression against us, and thus you deserve blame and you will pay a great price. ${ }^{62}$

This quotation justifies IS's struggles as a defensive war and portrays a binary worldview consisting of Islam and the mujāhidīn on one side and Western governments on the other. In other parts of Dabiq, Jews and Russia are added as part of the list of Western enemies. The polarized "us versus them" frame is consolidated by emphasizing the ongoing war against Islam conducted by the West. Western forces are continuously referred to as "crusaders," appealing to a master narrative with connotations of the historical precedent of non-Muslim powers who "seek to conquer and destroy the Muslim world and its holy places." 63 The social 
distance is reinforced through a process of "othering," which distinguishes the actors from each other ${ }^{64}$ Individuals from the West are negatively defined as kuffar (unbeliever) and tawaghit (polytheist). The pejoratives are emphasized by statements from Osama bin Laden, who stated that "The world today is divided into two camps," and former president George W. Bush's statement that "Either you are with us or you are with the terrorists."65

Also important in the diagnostic framing are descriptions of how Western values and practices result in a wide range of social problems. ${ }^{66}$ The theocratic governance under which IS is operating views Western development and sexual liberation as a significant part of the problem they are fighting.

[T]he West was plunged into a downward spiral of sexual deviance and immorality. With it came a whole slew of sexually transmitted diseases [...] as men and women let their lusts overwhelm their judgement and lead them to engage in fornication and "experiment" with a myriad of shaytān̄̄ [satanic] methods of fulfilling their desires. ${ }^{67}$

Similar to other fundamentalist religious organizations, IS considers their version to be the only true interpretation of Islam and considers those who do not acknowledge their religious authority as apostates and enemies of IS. In Dabiq, Shiites are seen as the biggest threat to Islam, and IS thus reinforces the sectarian conflict between Shiites and Sunnis that has been downplayed by other extremist Sunni organizations. ${ }^{68}$ The rhetoric of religious hate is pervasive in the magazine, and Shiites are generally referred to with the degrading term "sawafi," "nusyari," or more specific terms such as the "dogs of the crusaders." ${ }^{69}$ IS's diagnosis of the problem also includes other extreme jihadist organizations and organizations against which they are fighting in Syria, including the Islamic Front, Nusra Front, al-Sahwa, The Free Syrian Army, the Peshmerga and the Kurdistan Workers' Party. They describe these groups as "murtaddin" (apostate) or "deviant factions" and criticize them for having a false interpretation of Islam and reconciling with enemies "at the expense of His pure religion.”70

The list of problems included in IS's collective action framing is vast and includes Western governments and Western values as well as false interpretations of Islam. The emphasis in the diagnostic framing is on those groups IS is facing on the battlefield, but the hypocritical policies of Western governments are also highlighted in IS rhetoric. In sum, everyone that does not acknowledge IS authority or the legitimacy of the caliphate in Syria and Iraq is diagnosed as an enemy and as part of the problem of false Islam and Western liberal values that IS wants to solve. 


\section{The solution: the caliphate}

In social movement theory, prognostic frames describe rhetoric that articulates possible solutions and addresses necessary actions. ${ }^{71}$ Most importantly, the problems described above are solved through the creation of an Islamist caliphate and a war against Western and alleged "apostate" regimes' governments involved in conflicts in Muslim countries. ${ }^{72}$ IS wants to assemble the fragmented Muslim population under a caliphate controlled by an extreme perpetuation of Islamic law.

From amongst the aspects of this great millah that have begun to fade from within the souls of many people and be viewed as nothing more than fantasy, is the notion that the Muslim Ummah (nation) should strive to be united behind a single imam (leader), fighting under his banner and empowering him to guard the landmarks of this religion and implement the Shari'ah (law) of Allah. ${ }^{73}$

The ambition is to expand the caliphate to include not only the Muslim world but also the entire globe, "filling the world with the truth and justice of Islam and putting an end to the falsehood and tyranny of jāhiliyyah [ignorance]." ${ }^{74}$ The caliphate will not only solve the problems of false interpretation of Islam and the persecution of Muslims but also be a way to establish a successfully functioning state. In IS propaganda, the caliphate will work for the Muslim population by improving infrastructure, repairing roads, cleaning cities and offering extensive healthcare to both children and the elderly. This was considered so important that it was even prioritized during the ongoing war.

In the midst of a raging war with multiple fronts and numerous enemies, life goes on in the Islamic State. The soldiers of Allah do not liberate a village, town or city, only to abandon its residents and ignore their needs. ${ }^{75}$

The caliphate is depicted as a haven for the oppressed Muslim population in which IS takes care of their inhabitants by improving infrastructure, repairing roads, cleaning cities, and providing education and healthcare.

The Islamic State provides the Muslims with extensive healthcare by running a host of medical facilities including hospitals and clinics in all major cities through which it is 
offering a wide range of medical services, from various types of complicated surgery to simpler services such as hijāmah [wet cupping]. ${ }^{76}$

IS propaganda highlights the positive changes performed by the organization in building a state, such as the creation of their own currency and the implementation of the state system Wilayat. ${ }^{77}$ The favourable lifestyle offered by the caliphate is further revealed through images of celebrations of Muslim holidays and programmes and activities such as prayers, lectures and competitions during Ramadan. IS also documents how they fulfil the humanitarian needs of the Muslim population by feeding "the needy" "78 and caring for orphaned children. The caliphate also has a more prophetic role in the rhetoric, and IS believes that the creation of a de facto state (the caliphate) serves as evidence of IS's religious sincerity and God's acceptance.

The establishment of the caliphate is not the only solution or prognosis in IS rhetoric. In an official speech given by al-Adnani in September 2014, IS held the US and Europe responsible for initiating the war in Iraq and Syria. Through an infamous statement, IS supporters are encouraged to retaliate against Western governments by carrying out attacks on both officials and civilians in countries that are part of the US-led coalition. ${ }^{79}$ Announcing the arrival of "A New Era" IS legitimate the use of terrorism:

The Muslims today have a loud, thundering statement, and possess heavy boots. They have a statement to make that will cause the world to hear and understand the meaning of terrorism, and boots that will trample the idol of nationalism, destroy the idol of democracy, and uncover its deviant nature ${ }^{80}$

Terrorism in the West is revenge for past harms committed against Muslim countries and populations, but the main strategic idea was that terrorism would restrain Western countries from interfering in the conflict in Syria and Iraq and make the establishment of the caliphate easier. Terrorism is also a way to show strength and serves as a warning not to interfere in conflicts in the Middle East. Western military intervention was used to "confirm" IS's worldview of a war between Islam and the West to recruit more foreign fighters.

The main solution, or prognosis, IS advocates and fights for is a theocratic caliphate ruled by sharia. IS has mapped their journey to statehood of their self-proclaimed caliphate in five stages through hijrah (emigration), jamaah (the consolidation of Muslims of various nationalities and orientation as citizens of the state), destabilizing thagut (destabilizing 
idolatry through long campaigns attacking the "tyrants"), tamkin (consolidation and territorial control) and khilafah (the creation of an Islamic Caliphate under the IS version of sharia). ${ }^{81}$ Their belief is that the oppressed Muslim population will be freed from the moral, political and military influence of the Western world through the caliphate. The caliphate is described as an effective way of uniting the Muslim Ummah and a goal for all Muslims. On the way to the IS caliphate, several temporary solutions are possible, and waging terrorism against the West is one of them.

\section{Motivation: military success and the forthcoming apocalypse}

Diagnostic and prognostic frames are often considered "cold" and rational. Social movements also need motivational frames that appeal to a broader spectrum of emotions including rage, enthusiasm, and joy as well as frames that emphasize the importance of immediate action. Motivational frames are the most direct frames that mobilize people to support a cause. ${ }^{82}$ Highlighting and visualizing injustice is crucial for motivation. Appeals to emotion and moral indignation, or "hot cognitions," are important motivational frames ${ }^{83}$ and include examples such as pictures in Dabiq of Muslim civilians killed across the world.

An important part of IS's motivational framing was its reports of military success. Dabiq frequently reported how IS made military advances and conquered new territories. When successes on the battlefield diminished, they increased their coverage of military success to try to establish an alternative narrative while also trying to reshape the perception of territorial loss as further confirmation of the approaching apocalypse. ${ }^{84}$ In the period analysed in this study, the advances were still dominant:

On Monday, the $25^{\text {th }}$ of Sha'ban, the mujāhidīn of the Islamic State succeeded in liberating the strategic town of Tal Afar in Wilayat Ninawa. ${ }^{85}$

The Islamic State announced the expansion of the Khilāfah to Sinai, Libya, Yemen, Algeria, and the Arabian Peninsula, accepting the bay'ât [allegiance] of the mujāhidīn in those lands. ${ }^{86}$

Motivational frames also include descriptions of the ways in which warriors convert from other jihadi groups, such as Nusra Front and Ahrar al-Sham, to join IS. In social movement theory, this type of emphasis on social movement success is described as the "rhetoric of change. ${ }^{~} 87$ This is the concept that mobilizing participants for a social movement is easier if 
that movement is considered successful and movements therefore have an incentive to exaggerate their own successes. For example, the military success of IS caught the attention of the global media, ${ }^{88}$ which resulted in an increase in the recruitment of foreign fighters. ${ }^{89}$

Not unlike other apocalyptical sects, IS uses a powerful apocalyptical motivational frame with references to prophetic signs depicting "the Hour," or the Day of Judgement. ${ }^{90}$

The Hour will not be established until the Romans land at al-A'maq or Dabiq (two places near each other in the northern countryside of Halab). Then an army from alMadinah of the best people on the earth at that time will leave for them. ${ }^{91}$

Recent political events combined with prophetic religious texts are used to argue that we are living in the last days. The forthcoming Day of Judgement is presented as a crucial reason to join the movement. Historically suicide is seen as illegal in Islam and self-sacrifice and martyrdom avoided in Sunni Islam, ${ }^{92}$ but exploiting religious devotion and loyalty as an important virtue IS portrays the act of dying as a martyr as the highest sign of virtue. Thus making suicide attacks as a legitimate and heroic act of war. They also highlight the importance of the Ummah (Muslim unity) and other important Islamic themes resonating with a broad Muslim audience.

IS's collective action framing attempts to reach broad segments of potential IS sympathizers. The emphasis on the wars in the Middle East and the hypocrisy of Western governments, decadent Western values and false interpretations of Islam resonates with many Muslims. Establishing the caliphate is also the ultimate goal for many - and the emphasis on social welfare schemes is especially appealing to a broad audience. While terrorism is controversial, the caliphate, IS's military successes and the forthcoming Day of Judgement have general appeal, which is characteristic of social movement framing. However, these attempts at mass mobilization are incongruous with the graphic descriptions and images of torture and cruelty in Dabiq.

\section{IS propaganda as subcultural provocation}

Violent jihadism in the West can be seen as a subcultural response to a feeling of alienation in Western society. ${ }^{93}$ Dabiq promotes violence and a romanticized view of war and honour in which the fellowship between "brothers" is central. This form of "jihadi cool," a trend of imitating the masculine Muslim warrior, ${ }^{94}$ has many parallels with the masculinity and view on violence promoted in street gangs and in street subcultures. ${ }^{95}$ Dabiq can therefore be seen 
not only as social movement framing but also as textual and visual expressions of a subculture.

\section{Provocations}

IS follows sharia doctrine and enforces severe sanctions, such as the death penalty, for theological, political and sexual deviance. ${ }^{96}$ IS does not always use a predetermined set of sanctions when implementing sharia; instead, it employs innovative execution methods. IS stages and documents executions to an extent not previously seen, using multiple cameras and putting substantial work into producing widely distributed movies. Graphic portrayals of decapitation resulted in major media attention at first, but the power to shock diminished over time. After a while, the media helped to "domesticate and decontextualize" the executions "by producing banal indifference rather than moral outrage." 97 IS then started multiple simultaneous executions, using children as executioners as well as other extreme methods, such as burning prisoners alive, to gain more attention. Dabiq covered this in great detail.

The burning of a Jordanian pilot on 3 January 2015 was covered extensively and promoted as retribution against acts of war that bombed regions controlled by IS. ${ }^{98}$ The burning was justified by presenting photos of children and infants burnt to death and followed the logic of an eye for an eye. The staged performance and documentation of the event still indicates that the extreme violence was a goal in itself and an integrated part of IS propaganda. In Dabiq, the execution is clearly visualized by selecting a large picture in which the pilot is standing in a cage covered in flames. He is holding his hands to his face in pain, but the flames are covering him completely, making his identification difficult. A smaller portrait of the pilot's face is placed on the same page. The article concludes with a picture of the charred corpse of "the murtadd pilot" with obvious parallels to the burnt Muslim children. ${ }^{99}$ This brutal execution - and its dramatic documentation - can seem incomprehensible and disproportionate to an outsider, but it can be construed as a meaningful and legitimate act within a subcultural framework. Subcultures embrace and cultivate otherness in active detachment from mainstream society. ${ }^{100}$ The otherness represented by IS is similar to that of criminal street cultures in which being feared is an important asset.

The magazine also displays children as violent perpetrators, ${ }^{101}$ and articles such as The Lions of Tomorrow show an IS child soldier dressed in camouflage and holding a gun. He is standing resolute above an executed prisoner - allegedly a member of the Israeli intelligence service - dressed in an orange prison suit with his face covered in blood. The image suggested is one of a young and proud warrior who has executed an enemy infidel: 
As the mujāhidīn of the Islamic State continue their march against the forces of kufr there is a new generation waiting in the wings, eagerly anticipating the day that it is called upon to take up the banner of īmān. These are the children of the Ummah of jihād, a generation raised in the lands of malāhim (fierce battles) and nurtured under the shade of Sharī'ah, just a stone's throw from the frontlines. ${ }^{102}$

IS's use of child soldiers and its video depicting children executing prisoners caused widespread shock and disgust. ${ }^{103}$ IS seems to have been actively trying to provoke in acts of what the subcultural theorist Cohen describes as "active spite and malice, contempt and ridicule, challenge and defiance."104

The coverage of the destruction of historical sites and artefacts in Dabiq is another IS provocation. This destruction has been aimed at what they define as a heritage of infidels and consists of statues, sculptures, buildings and engravings with important cultural history. In an article in the eighth edition of Dabiq ${ }^{105}$ thoroughly illustrates destruction in which archaeological objects reported to be up to 3000 years old are knocked over and smashed with sledgehammers and jackhammers. ${ }^{106}$ IS justifies the destruction of historical objects in a religious framework, a practice known as iconoclasm, ${ }^{107}$ but there is also an element of general vandalism to these actions. Cohen describes the malice in deviant behaviour and how individuals receive pleasure from others' dismay, a type of "schadenfreude."108 These actions can be seen as similar to gang members conducting vandalism "for its own sake,"109 and the coverage of this destruction in Dabiq can appeal to those fascinated by vandalism in general.

Arguably, the call for terrorist attacks in the West - as well as the attacks themselves can also be seen more as provocative actions than strategic military manoeuvers. For example, the language in the infamous call for terrorist attacks in the West is strikingly spiteful:

If you can kill a disbelieving American or European - especially the spiteful and filthy French - or an Australian, or a Canadian, or any other disbeliever from the disbelievers waging war, including the citizens of the countries that entered into a coalition against the Islamic State, then rely upon Allah, and kill him in any manner or way however it may be. ${ }^{110}$

The common element in explicit violence, child soldiers, the destruction of historical sites and artefacts, and terrorism is that despite their religious, military or other form of justification, 
the graphic details and emphasis they receive in Dabiq indicates that they also play another role. Obvious provocations will attract the interest of the international media, will help draw the attention of a particular group of people especially interested in violence and vandalism, and, following a subcultural logic emphasizing sometimes extreme otherness, can also be a goal in itself for people in the organization.

\section{Celebration of violence and machismo}

A subculture is usually aware of its otherness. This otherness can be embraced and cultivated, but it will also exclude those who do not identify with or belong to the subculture. ${ }^{111}$ The extensive use of pictures in the magazine visualizes the style promoted by the jihadi subculture. The pictures display a culture of masculinity and include a wide variety of things, such as clothes, vehicles, weapons, guns, violence, honour and death. The ideal of masculinity is the Muslim warrior who fights in a jihad, a mujāhidīn. Dabiq creates and projects an image of a group consisting of men characterized as resolute, tough and masculine. The principles of male honour and individual self-sacrifice are praised, and death is glorified. War and honour are romanticized, and allow a jihadist to demonstrate that he is not a coward, passive, weak or feminine. The ultimate effort to reject these negative features and "do" masculinity is dying and gaining the status of a martyr, ${ }^{112}$ a shahid. Cottee and Hayward argue that rather than emerging from political goals, terrorism can be seen as the result of "existential frustration" and a desire for excitement, ultimate meaning and glory. ${ }^{113}$ Thus, subcultural theory is highly relevant when studying IS and its rhetoric in Dabiq.

An article in honour of the martyr Abu Dujanah al-Khurasani quotes him expressing his love for jihad and the honour of dying in battle.

They used to say, "Some love kills." I do not find that to be true except with the love of jihād, for this love will either kill you with sorrow if you decide to sit and abandon jihād, or it will kill you, making you a martyr fī sabīlillāh if you decide to answer the call. You only have to choose between one of these two deaths. ${ }^{114}$

IS glorifies violence with the help of religious scripture both to motivate its warriors and to attract new fighters. The slogan "know that Jannah is beneath the shades of swords"115 derives from a central hadith ${ }^{116}$ and is common in the magazine.

Dabiq mainly targets men. Other platforms and media channels are used to recruit women. For example, Peresin and Cervone describe a "jihadi girl power subculture" present 
on social media, ${ }^{117}$ but this is absent in Dabiq, which has no pictures depicting women, who are largely discussed rather than addressed. In the quotation below, a warrior is described as leaving behind a pregnant wife to travel and fight for the caliphate.

\begin{abstract}
Abū Qudāmah was a strong young man who left West London, United Kingdom in 2012 with his best friend Abū Mu'āwiyah to answer the call of jihād in Shām. So driven was Abū Qudāmah to fight for the cause of Allah and to seek the greatest of rewards, that he left the UK two months before his baby daughter was born. ${ }^{118}$
\end{abstract}

The portrayal of the masculine warrior is one of a man prioritizing comradeship, war and existential worries over his responsibility to care for his family. The rejection of mainstream values for more subcultural and extreme ones is common in subcultures, but it can also be seen as the ultimate celebration of machismo.

\title{
Excitement seeking, stardom and popular culture
}

The magazine often contains tributes and interviews with jihadists and martyrs who have achieved respect, fame and stardom. Young aspiring jihadists are radicalized not only through a religious or political processes but also by adopting a specific way of talking, walking or dressing themselves through imitation. ${ }^{119}$ Sageman argues that imitating terrorists is fashionable and describes how young Muslims see jihad as intriguing and exciting. ${ }^{120}$ The socalled "jihadi cool" creates a seductive subculture, attracting young people to participate in global Islamist terrorism because it is considered cool and exciting to be part of a "clandestine undertaking" as a part of a counterculture to Western mainstream society. ${ }^{121}$

One of these tributes is to Abdelahim Abaaoud, who is interviewed about his jihad in Belgium. As part of a failed terror plot in November 2015, he describes how he was pursued by Western intelligence in an intense and exciting game of "cat and mouse."

After the raid on the safe house, they figured out that I had been with the brothers and that we had been planning operations together. So, they gathered intelligence agents from all over the world - from Europe and America - in order to detain me. ${ }^{122}$

In describing his journey back to Syria, he explains how the police failed to apprehend him even when he was stopped by an officer but was not recognized. An image was constructed of an underdog eluding intelligence agents from all over the world and demonstrating skills, 
intelligence and a cool head. In a subcultural context, this narrative can create recognition and an exciting figure with whom individuals wish to identify themselves. They may not necessarily identify themselves as a "terrorist" but instead embrace a lawless identity by living outside the law-abiding community and rejecting mainstream norms and practices. ${ }^{123}$

Flags are a visual tool frequently used to unite people under a common symbol. The soldiers in Dabiq are often posed smiling while holding a black and white IS-flag and weapons that express strength and a potential for violence. A significant gesture frequently made by both children and adults is the lifting of the right hand with a closed fist while the index finger is pointing upward. This is understood as a symbol for the number one and has religious connotations by referring to tawhid (the oneness of God). However, as part of the jihadi subculture, the symbolic meaning can also be considered a gang symbol. ${ }^{124}$ Gang members often use gang symbols to express support and community within their respective groups. This sign is easy to imitate and demonstrates support for IS on a transnational level by breaking down language barriers for supporters who do not speak Arabic. ${ }^{125}$

The subcultural style visible in the magazine is also promoted through visual and audio-visual entertainment in the form of poems, battle hymns (nasheed) and propaganda videos. They shrewdly combine a reservoir of symbols and clothes while maintaining "the archaic, the religious and the contemporary cool" ${ }^{126}$ within the genre of so-called popjihadism. ${ }^{127}$ While IS religiously rejects bid'ah (innovation), they still utilize modern tools in the production of propaganda, and Dabiq contains advertisements promoting nasheeds and propaganda videos. The videos are often illustrated with miniature pictures showing one or more clips from the video; the magazine also creates an overview of the "best" videos, promoted them through a top ten list called Selected Ten. These videos have a high production quality and an action-based style and plot, resembling the trailers of films produced in Hollywood.

The elements of excitement seeking, stardom and popular culture in Dabiq is particularly appealing to young men concerned not only with religion but also the action and fame that are deeply embedded in Western popular culture. Violence as spectacle is an integrated part of attraction, but the fact that it is real also intersects with more marginal Internet-based phenomena such as the video distribution of violent acts and murders in "snuff films" through gore/shock sites. ${ }^{128}$ For insiders, these features are strong indicators of relatively closed subcultures celebrating real-time violence, while for outsiders they mainly create disgust and rejection. 


\section{Discussion and conclusion}

The radicalization process of an individual does not occur in a vacuum; it is rooted in specific and social environments. ${ }^{129}$ Sageman describes this environment as a "loose network of people" who are politically active, inspired by a utopia and reject societal values. ${ }^{130}$ This environment can also be considered a myriad of networks that consist of an informal structure of vague, diffuse and porous borders - a social blob. ${ }^{131} \mathrm{We}$ argue that this type of environment or radicalization can be inspired by a multitude of different - and sometimes conflicting - forms of organization as well as organizational and rhetorical logics. In this paper, we have emphasized the conflict in IS propaganda between social movement framing that attempts to mobilize as many supporters as possible and the more subcultural appeal to marginal groups and a drive toward provocation.

Gerges points out that all jihadist groups sanction spectacular violence to exploit its political and psychological effect. By establishing the caliphate while displaying spectacular violence IS managed to overshadow Al Qaeda. As in many other terrorist groups, the appeal to violence is both a strength and flaw in IS. This can be seen in different terrorist organisations, from Baader-Meinhof Group, Basque Homeland and Liberty, to the Irish Republic Army, and Al Qaeda. ${ }^{132}$ Terrorist organizations can attract attention and thus new recruits by the use of violence, but at the same time they risk losing mainstream support. In the case of Al Shabaab, the use of excessive violence was an important reason for why it was rejected in the Somali diaspora. ${ }^{133}$ We will still argue that with the graphic details and stylistic staging of violence in Dabiq, IS has taken terrorist organisations symbolic use of violence to a new level.

For IS, creating visual and mediatized spectacles of violence has been an important strategy to draw attention and supporters willing to travel to Syria and Iraq to engage in violent battle. Images of the destruction of cultural artefacts, innocent victims murdered by enemy forces, the execution of enemy combatants, soldiers posing with corpses and child soldiers are routinely portrayed in Dabiq. Promoting violence as spectacle ensures the organization's place in news media headlines, draws more readers to the magazine, and draws more recruits to the organization. This propaganda attracts a particular group of individuals drawn to the excitement of the jihadist lifestyle ${ }^{134}$ and fascinated by the violence depicted. The violent, ritualistic actions dramatized and promoted in Dabiq can be seen as a symbolic way of striking back against the perceived oppression from the West or mainstream Western society. Research on subcultures such as street gangs, hooligans and punks shows how similar methods of "striking back" or just provoking mainstream audiences appeal to selected 
marginalized groups. ${ }^{135}$ Through an active detachment from mainstream society, subcultures express their opposition by embracing and cultivating all different forms of otherness. ${ }^{136}$

At the same time, the excessive documentation and graphic illustrations of violence will be repulsive for most audiences and probably counter to the goal of mass mobilization. Large segments of IS propaganda portray effective state building, such as the construction of hospitals and schools. This can be seen as supporting the main prognostic frame (solution) of IS: the building of an Islamic Caliphate. Combined with the widespread diagnostic (description of problem) frame criticizing Western government, Western values and false Islam, this solution has widespread appeal in Muslim communities. In fact, most of the Dabiq propaganda can be considered traditional social movement framing. IS propaganda also changes with the success of IS on the battlefield. The e-magazine changed its name to Rumiyah after IS lost Dabiq, and the emphasis on the forthcoming apocalypse was downplayed after the decreasing military successes. Instead, the focus seemed to be on insisting on military success in an attempt to maintain the "rhetoric of change" that was so successful in the beginning. ${ }^{137}$ Now, celebrating an utopian past the "narrative of nostalgia" might be exploited as a result of the short-lived success of the caliphate ${ }^{138}$.

Social movement and subcultural perspectives are usually seen as mutually exclusive and often used illustratively by different scholars in radicalization research. They suggest different rhetorical strategies for organizations. For example, this study explains the difficulty in understanding how promoting violence as a spectacle can be effective method of social movement framing when targeting large segments of the population. However, when emphasizing social movement or subcultural frameworks, the question should instead ask why we should assume that IS (or any other organization) is rhetorically coherent. When studying Dabiq, the contrasts between the different forms of propaganda and different articles in the magazine are more striking than any overall similarities. Rhetorical ambiguity can be advantageous because it allows different audiences to become engaged at the same time, but it can also simply reflect different parts, tendencies and languages in an organization. ${ }^{139}$ IS is operating in a potent and discordant area, in which a multitude of political subcultures ${ }^{140}$ and social movements have emerged, and Dabiq propaganda reflects this.

Previous research on radicalization has emphasized either social movement theory or subcultural theory. We argue that to understand IS and other similar terrorist or extremist organizations, studies should include both perspectives. This can help capture the tension between the different parts of these organisations' propaganda. IS's appeal to a broader audience through raising the concerns of the Muslim majority, fits well with a social 
movement rationale, and attempts at state-building. IS's promotion and graphic description of excessive violent actions might seem counterintuitive within such a perspective, but it makes sense when seeing how it appeals to a subcultural minority drawn toward otherness and extreme violence. The rhetorical ambiguity was thus a result of attempts at both attracting families to the caliphate and warriors to fight wars. Using violence to create extreme spectacles is a double-edged sword. While it can create media interest and attract excitementseeking young warriors, it impairs the organization both externally and internally and establishes it as a marginal phenomenon.

This study has emphasized the rhetoric in Dabiq, but the tensions between social movement and subcultural dynamics probably cut through many other aspects of the organization as well, including organizational socialization, military strategy and training, recruitment processes and the characteristics of its members. Radicalization and terrorism is a complex phenomenon, ${ }^{141}$ and the radicalization processes and recruitment into extreme Islamist groups consists of multiple and sometimes contradicting dimensions. Future efforts to understand IS and similar organizations must draw on both social movement and subcultural theory in addition to the more traditional religious and political science approaches. A combination of the two could even help illuminate organizational contradictions and rhetorical ambiguities and thus provide a more comprehensive and nuanced understanding of terrorism.

\section{Notes}

1. Ian R. Pelletier, Leif Lundmark, Rachel Gardner, Gina S. Login, and Ramazan Kilinc, "Why ISIS's Message Resonates: Leveraging Islam, Sociopolitical Catalysts, and Adaptive Messaging," Studies in Conflict \& Terrorism 39, no. 10 (2016): 871-899.

2. Aaron Y. Zelin, "Picture Or It Didn't Happen: A Snapshot of the Islamic State's Official Media Output," Perspectives On Terrorism 9, no. 4 (2015): 85-97.

3. Charlie Winter, "The Virtual 'Caliphate': Understanding Islamic State's Propaganda Strategy," Quilliam, 2015, http://www.stratcomcoe.org/charlie-winter-virtualcaliphate-understanding-islamic-states-propaganda-strategy (accessed November 11, 2016).

4. Ibid.

5. William McCants, The ISIS Apocalypse (New York: St. Martin's Press, 2015).

6. Daniel Byman, Al Qaeda, the Islamic State, and the global jihadist movement: What everyone needs to know (Oxford: Oxford University Press, 2015).

7. Quintan Wiktorowicz, Islamic Activism: A Social Movement Theory Approach (Bloomington: Indiana University Press, 2004); David A. Snow and Scott C. Byrd, "Ideology, framing processes, and Islamic terrorist movements," Mobilisation: An International Quarterly Review 12, no. 1 (2007): 119-136; Anja Dalgaard-Nielsen, 
"Studying Violent Radicalization In Europe I: The Potential Contribution Of Social Movement Theory," DIIS Working Paper (Danish Institute for International Studies: Copenhagen, 2008).

8. IFRI (2018) assessed the profiles of 137 individuals sentenced in France for cases of related to jihadism. Basra and Neuman (2016) examine the relevance of 79 European jihadists with criminal background. Lia and Nesser (2016) describe the background of Norwegian foreign fighters. PST (2016) estimates that around 68 percent of radical extremists in Norway have a criminal past. Further details see: Marc Hecker, "137 Shades of Terrorism: French Jihadists Before the Court," IFRI, French Institute of International Relations, 2018, https://www.ifri.org/sites/default/files/atoms/files/hecker 137 shades of terrorism 2 018.pdf; Rajan Basra and Peter R. Neumann, "Criminal Past, Terrorist Futures: European Jihadists and the New Crime-Terror Nexus," Perspectives on Terrorism 10. no. 6 (2016): 25-40; Brynja Lia and Petter Nesser, "Norske Muslimske Fremmedkrigere," Nytt Norsk Tidsskrift 31. no. 4 (2014): 399-416; PST, "Hvilken Bakgrunn har personer som frekventerer ekstreme islamistiske miljøer i Norge før de blir radikalisert?," Politiets sikkerhetstjeneste, 2016, https://www.pst.no/globalassets/artikler/utgivelser/radikaliseringsprosjektetsrapport.pdf; Suraj Lakhani, "Extreme Criminals: Reconstructing Ideas of Criminality through Extremist Narratives," Studies in Conflict \& Terrorism (2018): 1-16.

9. Daniela Pisoiu, "Subcultural Theory Applied to Jihadi and Right-Wing Radicalization in Germany," Terrorism and Political Violence 27, no. 1 (2015): 9-28; Simon Cottee, "Jihadism as a Subcultural Response to Social Strain: Extending Marc Sageman's "Bunch of Guys" Thesis," Terrorism and Political Violence 25, no. 5 (2011): 730-751; Ann-Sophie Hemmingsen, "Viewing jihadism as a counterculture: potential and limitations," Behavioral Sciences of Terrorism and Political Aggression 7, no. 1 (2014): 3-17.

10. Petter Nesser, Islamist Terrorism In Europe: A History (London: Hurst \& Company, 2015); McCants (see note 5 above).

11. Adil Rasheed, ISIS: Race to Armageddon (New Delhi: Vij Books India Pvt Ltd., 2015): 1.

12. McCants (see note 5 above).

13. Rhys Dubin, "ISIS 2.0 Is Really Just the Original ISIS," Foreign Policy, April 3, 2018, http://foreignpolicy.com/2018/04/03/isis-2-0-is-really-just-the-original-isis/ (accessed May 9, 2018).

14. Michael Page, Lara Challita, and Alistair Harris, "Al Qaeda in the Arabiam Peninsula: Framing Narratives and Prescriptions," Studies in Conflict \& Terrorism 23, no. 2 (2011): 150-172.

15. Ahmed, Al-Rawi, "Video games, terrorism, and ISIS's Jihad 3.0," Terrorism and Political Violence, (2016): 1-21.

16. Daniel Eriksen, "Slik bruker IS vestens popkultur til propaganda," NRK, June 13, 2016, https://www.nrk.no/urix/x1/slik-bruker-is-vestens-popkultur-til-propaganda1.12991486 (accessed October 17, 2016).

17. Harleen K. Gambhir, "Dabiq: The Strategic Messaging of the Islamic State," Institute for the Study of War, August 15, 2014, http://www.understandingwar.org/sites/default/files/Dabiq\%20Backgrounder_Harleen \%20Final.pdf (accessed December 14, 2016).

18. The magazine alone does not radicalize anyone, but combined with other factors, it can reinforce or create interest for the radical worldview that inspires terrorism. This is for example shown in the example of Cubeyda Jama (19) who was arrested for 
attempted to reach Syria, where they found digital copies of Dabiq in his backpack. Further details see: Lydia Willgress, "Teenager who spent student loan trying to join Isil and used a 'step-by-step guide to terrorism' is jailed, The Telegraph, Julay 28, 2016, https://www.telegraph.co.uk/news/2016/07/28/teenager-who-spent-student-loantrying-to-join-isis-and-used-a-s/

19. Brandon Colas, "What Does Dabiq Do? ISIS Hermeneutics and Organizational Fractures within Dabiq Magazine," Studies in Conflict \& Terrorism 40, no. 3 (2017): 173-190.

20. McCants (see note 5 above).

21. Haroro J. Ingram, "An Analysis of Inspire and Dabiq: Lessons from AQAP and Islamic State's Propaganda War,” Studies in Conflict \& Terrorism, (2016): 1-19.

22. Haroro J. Ingram, “An analysis of Islamic State's Dabiq magazine,” Australian Journal of Political Science 51, no. 3 (2016): 458-477.

23. Gambhir (see note 17 above); Winter (see note 3 above).

24. Ingram (see note 21 above); Matteo Vergani and Ana-Maria Bliuc, "The evolution of the ISIS'language: a quantitative analysis of the language of the first year of Dabiq magazine," Sicurezza, Terrorismo e Società 1, no. 2 (2015): 7-20.

25. Kay L. O'Halloran, Sabine Tan, Peter Wignell, John A. Bateman, and Andrew Vande Moere, "Interpreting text and image relations in violent extremist discourse: A mixed methods approach for big data analytic," Terrorism and Political Violence, (2016): 121.

26. Agathe Christien, "The Representation of Youth in the Islamic States's Propaganda Magazine Dabiq,” Journal of Terrorism Research 7, no. 3 (2016): 1-8; Carol K. Winkler, Kareem El Damanhoury, Aaron Dicker, and Anthony F. Lemieux, "The medium is terrorism: Transformation of the about to die trope in Dabiq," Terrorism and Political Violence, (2016): 1-20.

27. Ingram (see note 21 above); Celine Marie I. Novenario, "Differentiating Al Qaeda and the Islamic State Through Strategies Publicized in Jihadist Magazines," Studies in Conflict \& Terrorism 39, no. 11 (2016): 953-967.

28. McCants (see note 5 above); Nesser (see note 10 above).

29. Jeroen Gunning, "Social movement theory and the study of terrorism," in Critical terrorism studies: A new research, edited by Richard Jackson, Marie Breen Smyth, and Jeroen Gunning (New York: Routledge, 2009), 156-177.

30. Mayer N. Zald and John D. McCarthy, "Resource Mobilization and Social Movements: A Partial Theory," in Social Movements In An Organizational Society, edited by William A. Gamson (New Brunswick: Transaction Publishers, 2009): 20.

31. Wiktorowicz (see note 7 above), 15.

32. Dalgaard-Nielsen (see note 7 above): 6 .

33. Doug McAdams, John D. McCarthy, and Mayer N. Zald, "Introduction," in Comparative Perspectives on Social Movements. Political Opportunities, Mobilizing Structures, and Cultural Framings, (Cambridge: Cambridge University Press, 1996).

34. Dalgaard-Nielsen (see note 7 above): 8.

35. Robert Benford and David A. Snow, "Framing Processes and Social Movements: An Overview and Assessment," Annual Review of Sociology 26, no. 1 (2000): 611-639.

36. Ibid., 614.

37. Ken Gelder, The Subculture Reader (London: Taylor \& Francis Group, 2005), 9.

38. Ken Plummer, The Chicago School: Critical Assessments of Leading Sociologists (Vol. 1-4, London: Routledge, 1997).

39. Shane Blackman, "Subculture Theory: An Historical and Contemporary Assessment of the Concept for Understanding Deviance," Deviant Behavior 35, no. 6 (2014): 498. 
40. Graeme Turner, British Cultural Studies: An Introduction (London: Unwin-Hyman, 1990).

41. Gelder (see note 37 above), 143.

42. Ibid., 1.

43. Simon Cottee and Keith Hayward, "Terrorists (E)motives: The Existential Attractions of Terrorism," Studies in Conflict \& Terrorism 34, no. 12 (2011): 963-986.

44. Cottee (see note 9 above).

45. Hegghammer, Thomas, Jihadi Culture: The Art and Social Practices of Militant Islamists (Cambridge: Cambridge University Press, 2017), 1.

46. Pisoiu (see note 9 above).

47. Andy Benneth and Keith Kahn-Harris, After Subculture: Critical Studies in Contemporary Youth Culture (New York: Palgrave Macmillan, 2004).

48. David Muggleton and Rupert Weinzierl, The post-subcultures reader (Berg publishers, 2003).

49. Paul Willis, Learning to Labour (London: Saxon House, 1997).

50. Jonathan Ilan, Understanding Street Culture: Poverty, Crime, Youth and Cool (Palgrave Macmillan, 2015); Philippe Bourgois, In search of respect: Selling crack in El Barrio (Vol. 10, Cambridge University Press, 2003).

51. ICCT (2016) estimate that 17 percent are female, over 90 percent originate from metropolitan areas, and between 6 and 23 percent are converts, but found no clear-cut profile. Similarly UNOCT (2017) found no one profile, but describe a typical fighter an economically and educationally disadvantaged young male. Further details see: Bérénice Boutin, "The Foreign Fighters Phenomenon in the European Union: Profiles, Threats \& Policies," ICCT, International Center for Counter-Terrorism, 2016, https://icct.nl/wp-content/uploads/2016/03/ICCT-Report_Foreign-FightersPhenomenon-in-the-EU 1-April-2016 including-AnnexesLinks.pdf; Hamed El-Said and Richard Barret, "Enhancing the Understanding of the Foreign Terrorist Fighters Phenomenon in Syria," United Nations Office of Counter-Terrorism, 2017, http://www.un.org/en/counterterrorism/assets/img/Report_Final_20170727.pdf

52. Scott H. Decker and David C. Pyrooz, "'I'm down for a Jihad': How 100 Year of Gang Research Can Inform the Study of Terrorism, Radicalization and Extremism," Perspectives on Terrorism 9, no. 1 (2015): 104-112.

53. Jonathan Ilan and Sveinung Sandberg, "How 'gangsters' become jihadists: Bourdieu, criminology and the crime-terrorism nexus," (forthcoming); Pisoiu; Cottee (see note 9 above).

54. Page et al. (see note 14 above): 153.

55. Tore Bjørgo, Root Causes of Terrorism: Myths, Reality and Ways Forward (New York: Routledge, 2005).

56. Steinar Kvale, and Svend Brinkmann, Learning the craft of qualitative research interviewing (Thousand Oaks: Sage Publications, 2009).

57. Anja Dalgaard-Nielsen, "Violent Radicalization in Europe: What We Know and What We Do Not Know," Studies in Conflict \& Terrorism 33, no. 9 (2010): 802.

58. Benford and Snow (see note 35 above): 617.

59. Ibid.

60. Wiktorowicz (see note 7 above); Benford and Snow (see note 35 above).

61. Jeffry R. Halverson, H.L. Goodall, Jr., and Steven R. Corman, Master Narratives of Islamist Extremism (New York: Palgrave Macmillan, 2011).

62. Al Hayat Media Center, "Issue 4: The Failed Crusade," Dabiq, October 11, 2014: 8.

63. Halverson et al. (see note 61 above), 124. 
64. Jon Garland and Neil Chakraborti, "Race', space and place. Examining identity and culture in rural Englan," Etnicities 6, no. 2 (2006): 159-177.

65. Al Hayat Media Center, "Issue 7: From Hypocricy to Apostasy. The Extinction of the Grayzone," Dabiq, February 12, 2015: 54.

66. Wiktorowicz (see note 7 above).

67. Dabiq 7 (see note 65 above): 57.

68. McCants (see note 5 above).

69. Dabiq 4 (see note 62 above): 18.

70. Dabiq 7 (see note 65 above): 39.

71. Benford and Snow (see note 35 above).

72. Quintan Wiktorowicz, "Anatomy of the Salafi Movement," Studies in Conflict \& Terrorism 29, no. 3 (2006) 207-239.

73. Al Hayat Media Center, "Issue 1: The Return Of Khilafah," Dabiq, July 5, 2014: 24.

74. Al Hayat Media Center, "Issue 5: Remaining an Expanding," Dabiq, November 21, 2014: 3 .

75. Dabiq 4 (see note 62 above): 27.

76. Al Hayat Media Center, "Issue 9: They Plot and Allah Plots," Dabiq, May 21, 2015: 25.

77. Charles C. Caris, and Samuel Reynolds, "ISIS Governance In Syria," Institute for the Study of War, Middle East Security Report 22, July 2014, http://www.understandingwar.org/sites/default/files/ISIS Governance.pdf (accessed October 17, 2016).

78. Al Hayat Media Center, "Issue 2: The Flood," Dabiq, July 27, 2014: 35.

79. Dabiq 4 (see note 62 above): 9.

80. Dabiq 1 (see note 73 above): 8 .

81. Ibid., 24; Rasheed (see note 11 above): 80.

82. Benford and Snow (see note 35 above).

83. William A. Gamson, "Constructing Social Protest," in Social Movements and Culture, edited by Hank Johnston and Bert Klandermans (University of Minnesota Press: Minneapolis, 1995), 85-106.

84. Anne Barnard, "After Losses in Syria and Iraq, ISIS Moves the Goal Posts," The New York Times, October 18, 2016

https://www.nytimes.com/2016/10/19/world/middleeast/islamic-state-syriairaq.html? r=0 (accesses February 15, 2017); Charlie Winter, "How the Islamic State Is Spinning the Mosul Battle," The Atlantic, October 20, 2016 https:/www.theatlantic.com/international/archive/2016/10/isis-mosul-propagandairaq-kurds-peshmerga/504854/ (accessed February 15, 2017); Zelin (see note 2 above).

85. $\quad$ Dabiq 1 (see note 73 above): 16.

86. Dabiq 5 (see note 74 above): 12.

87. David Meyer and William A. Gamson, "Framing political opportunity," Comparative Perspectives on Social Movement, edited by Doug McAdam, John D. McCarthy, and Mayer N. Zald (Cambridge University Press: Cambridge, 1996).

88. Rasheed (see note 11 above).

89. Brynjar Lia and Petter Nesser, "Norske muslimske fremmedkrigere," Nytt Norsk Tidsskrift 4, no. 31 (2014) 399-416.

90. McCants (see note 5 above).

91. Dabiq 1 (see note 73 above): 4.

92. David Cook, Martyrdom in Islam (New York: Cambridge University Press, 2007)

93. Hemmingsen (see note 9 above). 
94. Marc Sageman, Leaderless Jihad: Terror Networks in the Twenty-First Century (Philadelphia: University of Pennsylvania Press, 2008).

95. Ilan (see note 50 above); Bourgois (see note 50 above).

96. Thomas Hegghammer, "Norske fremmedkrigere i går og i dag," Norsk Statsvitenskapelig Tidsskrift 4, no. 30 (2014): 277-88.

97. Eamonn Carrabine, "Just Images: Aesthetics, Ethics and Visual Criminology," British Journal of Criminology 52, no. 3 (2012): 467.

98. Dabiq 7 (see note 65 above): 5.

99. Ibid., 8 .

100. Gelder (see note 37 above).

101. Christien (see note 26 above).

102. Al Hayat Media Center, "Issue 8: Shari'ah Alone Will Rule Africa," Dabiq, March 30, 2015: 20.

103. Jessica Stern and JM. Berger, "'Raisin tomorrow's mujahideen': the horrific world of Isis's child soldiers," The Guardian, March 10, 2015, https://www.theguardian.com/world/2015/mar/10/horror-of-isis-child-soldiers-stateof-terror (accessed October 10, 2016).

104. Cottee (see note 9 above): 736 .

105. Dabiq 8 (see note 102 above): 22 .

106. Bjørn Egil Halvorsen, "Derfor ødelegger IS verdensarven," Aftenposten, December 11, 2015, http://www.aftenposten.no/amagasinet/Derfor-odelegger-IS-verdensarven60824b.html?spid rel=2 (accessed October 10, 2016).

107. Finbarr B. Flood, "Between Cult and Culture: Bamiyan, Islamic Iconoclasm, and the Museum," The Art Bulletin 84, no. 4 (2002): 641-659.

108. Albert K. Cohen, "Delinquent Boys: The Culture of the Gang," in Criminological Theory: Past to Present, edited by Francis T. Cullen, Robert Agnew R., and Pamela Wilcox (Oxford University Press: New York, 1995), 186-190.

109. Cottee (see note 9 above): 736 .

110. Dabiq 4 (see note 62 above): 9.

111. Gelder (see note 37 above).

112. James Messerschmidt, "Masculinities and Crime," in Criminological Theory: Past to Present, edited by Francis T. Cullen, Robert Agnew R., and Pamela Wilcox (Oxford University Press: New York, 1995), 354-365.

113. Cottee and Hayward (see note 43 above).

114. Al Hayat Media Center, "Issue 3: A Call to Hijrah," Dabiq, September 10, 2014: 28.

115. Al Hayat Media Center, "Issue 6: Al Qa'idah of Waziristan: A Testimony from Within," Dabiq, December 29, 2014: 11

116. Cecilie Hellestveit, "Den islamske staten (IS) - forankring, virkemidler og ideologi," in Islamisme: Ideologi og trussel, edited by Øystein Sørensen, Bernt Hagtvet, and Nik. Brandal (Oslo: Dreyer Forlag, 2016).

117. Anita Peresin and Alberto Cervone, "The Western Muhajirat of ISIS," Studies in Conflict \& Terrorism 38, no. 7 (2015): 506.

118. Dabiq 7 (see note 65 above): 46.

119. Manni Crone, "Religion and Violence: Governing Muslim Militancy through Aesthetic Assemblages," Millennium: Journal of International Studies 43, no. 1 (2014): 291-307.

120. Sageman (see note 94 above).

121. Ibid, 160.

122. Dabiq 7 (see note 65 above): 72 .

123. Cottee and Hayward (see note 43 above). 
124. Nathaniel Zelinksy, "ISIS Sends a Message. What Gestures Say About Todays Middle East," in Foreign Affairs Anthology Series: The ISIS Crisis, September 3, 2014, https://www.foreignaffairs.com/articles/middle-east/2014-09-03/isis-sendsmessage (accessed October 12, 2016).

125. Crone (see note 119 above).

126. Daniela Pisoiu, "Subculture: The third wave of European jihad," Journal for Deradicalization 2, (2015): 169.

127. Barbara Franz, "Popjihadism: Why Young European Muslims Are Joining the Islamic State," Mediterranean Quarterly 26, no. 2 (2015): 5-20.

128. Lessley Anderson, "Snuff: Murder and torture on the internet, and the people who watch it," The Verge, June 13, 2012, http://www.theverge.com/2012/6/13/3076557/snuff-murder-torture-internet-peoplewho-watch-it (accessed January 16, 2017).

129. Pisoiu (see note 9 above).

130. Marc Sageman, "Hofstad Case \& The Blob Theory," Theoretical Frames on Pathways to Violent Radicalization, ARTIS Research and Risk Modeling (2009): 19.

131. Ibid.

132. See e.g. Stefan Aust, The Baader-Meinhof Complex (London: Random House, 2008); Dipak K. Gupta, Understanding Terrorism and Political Violence: The life cycle of birth, growth, transformation, and demise (New York: Routledge, 2008); Teresa Whitfield, Endgame for ETA: Elusive Peace in the Basque Country (New York: Oxford University Press, 2014); Byman (see note 6 above).

133. Sara K. Thompson and Sandra M. Bucerius, "Transnational radicalization, diaspora groups, and within-group sentiment pools: Young Tamil and Somali Canadians on the LTTE and al Shabaab," Terrorism and Political Violence, (2017): 1-18.

Fawaz A. Gerges, ISIS: A History (Princeton: Princeton University Press, 2016), 232.

134. Cottee and Hayward (see note 43 above).

135. James Treadwell and Jon Garland, "Masculinity, Marginalization and Violence. A Case Study of the English Defence League," British Journal of Criminology 51, no. 4 (2011): 621-634; Stanley Cohen, Folk Devils and Moral Panics, (edition 3, Abington: Routledge, 2002); Dick Hebdige, Subculture: the meaning of style (Abington:

Routledge, 1979).

136. Gelder (see note 37 above).

137. Meyer and Gamson (see note 87 above).

138. Colin P. Clarke and Haroro J. Ingram, "Defeating the ISIS Nostalgia Narrative," Foreign Policy Research Institute, April 18, 2018, https://www.fpri.org/article/2018/04/defeating-the-isis-nostalgianarrative/\#.WtjLNdyARql.twitter (accessed April 24, 2018).

139. Francesca Polletta, "It was like a fever," Storytelling in Protest and Politics (Chicago: University of Chicago Press, 2006).

140. Pisoiu (see note 126 above).

141. Randy Borum, "Radicalized into Violent Extremism I: A Review of Social Science Theories," Journal of Strategic Security 4, (2011). 